\title{
The impact of FDI on income inequality in Egypt
}

\author{
Hebatalla Rezk ${ }^{1} \cdot$ Goma Amer $^{1} \cdot$ Nahla Fathi $^{1} \cdot$ Sizhong Sun $^{2}$ (D)
}

Received: 5 July 2021 / Accepted: 25 November 2021 / Published online: 20 January 2022

(c) The Author(s) 2022

\begin{abstract}
This study examines the impact of inward foreign direct investment (FDI) on income inequality in Egypt over the period from 1975 to 2017. We find that a one per cent increase in FDI inflows (as a percentage of gross fixed capital formation) results in 0.0188 reduction of the Gini coefficient. The finding is robust to different specifications of the empirical model and potential endogeneity of FDI inflows. The negative impact of FDI inflows suggests that Egyptian policymakers shall continue and strengthen the open-door policy, which has the added benefit of improving income inequality.
\end{abstract}

Keywords FDI $\cdot$ Income inequality $\cdot$ Globalisation $\cdot$ Egypt

JEL Classification F21 F62 - D31 · C36

\section{Introduction}

As a key component of globalisation, foreign direct investment (FDI) is likely to influence income inequality in the host country. On the one hand, economists and policymakers believe that FDI can improve income inequality by contributing to the growth and development of host countries, through such channels as transfer of management skills and modern technology, exporting market access, and human

Sizhong Sun

sizhong.sun@jcu.edu.au

Hebatalla Rezk

hebatalla.rezk@yahoo.com

Goma Amer

profgoma@yahoo.com

Nahla Fathi

nahlasalem2006@yahoo.com

1 Economics Department, Zagazig University, Zagazig, Egypt

2 College of Business Law and Governance, Division of Tropical Environment and Societies, James Cook University, Townsville, Australia 
capital development. On the other hand, despite FDI having played an important role in advancing economic development, it is also accountable for deteriorating income inequality, for instance, by aggravating wage differentials in host countries and repatriation of FDI firms' profit to the home countries.

Examining inequality issues is important because high levels of income inequality can reduce the effectiveness of developmental policies, for example poverty alleviation (Kaulihowa and Adjasi 2018). In addition, rising income inequality can lead to socio-political instability, which in turn reduces investment, economic growth, and undermines sustainable development (Ravinthirakumaran and Ravinthirakumaran 2018). The global spread of social movements in the post-2008 global financial crisis and the 2011 Arab Spring in the Middle East and North Africa have made the issue of income inequality more prominent (Verme et al. 2014). Therefore, investigating the relationship between FDI and income inequality will present potentially important implications for policymakers.

This study examines the impact of inward FDI on income inequality in Egypt. Since the mid-1970s, Egypt has introduced various legislations to open up its economy, resulting in a significant increase in the inflow of FDI. By the end of 2017, Egypt became the largest recipient of inward FDI in Africa, with an inflow of \$7.4 billion (CNUCED 2018). At the same time, the Egyptian economy suffered from an increasing income inequality. According to the Standardized World Income Inequality Database (SWIID), Egypt's Gini coefficient (post tax and transfer) increased from 36.7 to 41.9 from 1975 to 2017 , reaching a peak of 42.8 in 2012 . The concurrent upward trending of FDI inflow and income inequality in Egypt calls for an investigation of their causality.

A number of studies have explored the impact of inward FDI on income inequality in Egypt, primarily in situations that use panel data, ${ }^{1}$ where Egypt is one member of the cross-section. However, countries differ in terms of culture, social welfare programs, and institutions, which may not be sufficiently controlled for in the panel data estimations. In addition, it is likely that the impact of FDI is different across different countries. In light of these challenges, this research focuses on a single country, Egypt, from 1975 to 2017.

Our contributions are twofold. First, we study how FDI affects income inequality in a single country. Utilizing the within-country variations to identify the impact, rather than the cross-country variations of many previous studies. Second, the findings from this study present significant policy implications for not only Egypt, but also other developing countries.

The rest of the paper is organized as follows: Sect. 2 reviews the related literature; Sect. 3 presents a brief overview of Egypt's FDI and income inequality; Sect. 4 discusses the method; Sect. 5 contains a description of the data, and the empirical results are presented in Sect. 6; Sect. 7 draws policy implications and concludes.

\footnotetext{
${ }^{1}$ See, for example, Kaulihowa (2018) and Pan-Long (1995).
} 


\section{Literature review}

Empirical studies investigating the relationship between FDI and income inequality have had mixed results. Some studies revealed FDI negatively affects income inequality, while the others found a positive or statistically insignificant effect of FDI. Below we briefly survey these studies and highlight the gap in existing literature.

FDI is found to negatively affect (reduce) income inequality in both within and cross-country studies. For within-country studies, a significantly negative impact from FDI on income inequality was found in Mexico from 1990 to 2000 (Jensen and Rosas 2007), China in the period of 1985-2007 (Mah 2013), Turkey between 1970 and 2008 (Ucal et al. 2016) and the USA from 1977 to 2001 (Chintrakarn et al. 2012). These studies suggest that a negative impact of FDI on income inequality can be observed in both developing and developed countries.

Compared with within-country studies, there are slightly more cross-country studies that discovered a negative impact. Adams (2008) found that FDI is negatively correlated with income inequality in 62 developing countries for the period 1985-2001. Similarly, Herzer and Nunnenkamp (2013) found that the long-run effect of FDI on income inequality is negative in eight European countries from 1980 to 2000. Ridzuan et al. (2014) concluded that an increase in the FDI inflows reduces income inequality in Malaysia, Indonesia, and Philippines between 1970 and 2008. In 13 Asia-Pacific economic cooperation developing economies over the period 1990-2012, Ravinthirakumaran and Ravinthirakumaran (2018) showed that FDI in the long run is negatively correlated with income inequality.

The inflow of FDI can also generate a significantly positive impact on income inequality, namely worsen the income inequality, in the host economies. Similar to the negative impacts, researchers have discovered such positive impacts in both cross and within country studies. The cross country studies include Alderson and Nielsen (1999) in 88 countries from 1967 to 1994, Alderson and Nielsen (2002) in the OECD countries over the period 1967-1992, Reuveny and Li (2003) in 69 developing and developed countries over the period 1960-1996, Herzer et al. (2014) in the selected Latin American countries from1980 to 2006, Choi (2006) in 119 countries from 1993 to 2002, and Grimalda et al. (2010) in the post-Soviet Union countries.

For within country studies, Mah (2002) examined the issue in Korea over the period 1975-1995, where he found the Gini coefficients tended to increase with FDI inflows. Similarly, Nunnenkamp et al. (2007) found that income distribution worsened with more FDI inflows in Bolivia. In China, FDI inflows were also found to worsen the income inequality (see for example Wan et al. 2007; Yu et al. 2011; Zhang and Zhang 2003).

A number of studies have found statistically insignificant effects of FDI on income inequality, for example Pan-Long (1995), Mahler et al. (1999), Bussmann et al. (2005), Milanovic (2005), Lee (2010), Sylwester (2005), and Wei (2009).

The impact of FDI on income inequality is likely to depend on some particular factors. Using an unbalanced panel dataset of 60 countries from 1970 to 1994, Lee et al. (2007) found an inverted-U shaped relationship between FDI and income 
inequality. The effect of FDI on inequality was positive at the low to intermediate levels of government size, while it was substantially negative in societies with a larger public sector. Using a panel of 73 developing and developed countries over the period 1970-2005 and a threshold regression approach, Lin et al. (2013) showed that FDI increased income inequality when a country achieves a threshold of human capital between 6.0 and 6.7 years of secondary schooling. Below this threshold however, FDI improves income distribution.

Kaulihowa et al. (2018) found a u-shaped effect of FDI on income inequality in 16 African countries. The FDI inflow first alleviated the inequality of income distribution. However, this effect diminished with further expansions of FDI inflow. Lin et al. (2015) explored the role of financial development in moderating the effect of FDI on income inequality in 42 developing and developed countries over the period 1976-2006, by employing a panel smooth transition regression technique. They found a positive impact of FDI on income inequality, which became stronger as a country's financial development improves.

Studies that explore FDI in Egypt mainly focus on two aspects: the determinants of FDI (for example Bhaumik and Gelb 2005; Naguib 2011), and the effect of FDI on economic development, growth and specific macroeconomic factors in the economy (for example Hanafy and Marktanner 2019; Massoud 2008). There is a lack of study that investigates FDI and income inequality in Egypt, despite some studies including Egypt as a member of the cross-section in their cross-country panel data estimations (see for example Kaulihowa and Adjasi 2018; Pan-Long 1995). Nevertheless, it may be preferable to consider countries separately because countries differ in cultural norms, institutions, and social welfare programs, which makes it difficult to control for in the panel data estimations (Ucal et al. 2016). Such kind of crosscountry differences likely contribute to contrasting findings in the previous studies. In light of this, this paper adds to the existing literature on FDI and income inequality by analyzing the relationship between FDI and income inequality in Egypt.

\section{Stylized facts of FDI and income inequality in Egypt}

Since the mid-1970s, Egypt has adopted an open-door economic policy, "Infitah", which featured the Egyptian legislature issuing several investment laws. The first and most prominent law, Law No. 43 (1974), aims at building an investment climate in which Arab and foreign investments play an important role in creating new production capacities and expanding existing production capacities, promoting the role of the private sector in the economy, as well as diversifying and aligning Egypt's economic structure with the requirements of global economic and social development.

The other laws include Law No. 32 (1977), Law No. 59 (1979), Law No. 230 (1989), Law No. 8 (1997) (The Investment Guarantees and Incentives Law), Law No. 83 (2002), Law No. 13 (2004), Law No. 94 (2005), Law No. 19 (2007), Law No. 114 (2008), Law No. 133 (2010), Law No. 14 (2012) and Law No. 95 (2015). These laws were issued with an aim to encourage FDI inflows into Egypt. For example, the Law No. 230 (1989) provided a number of incentives to attract FDI 


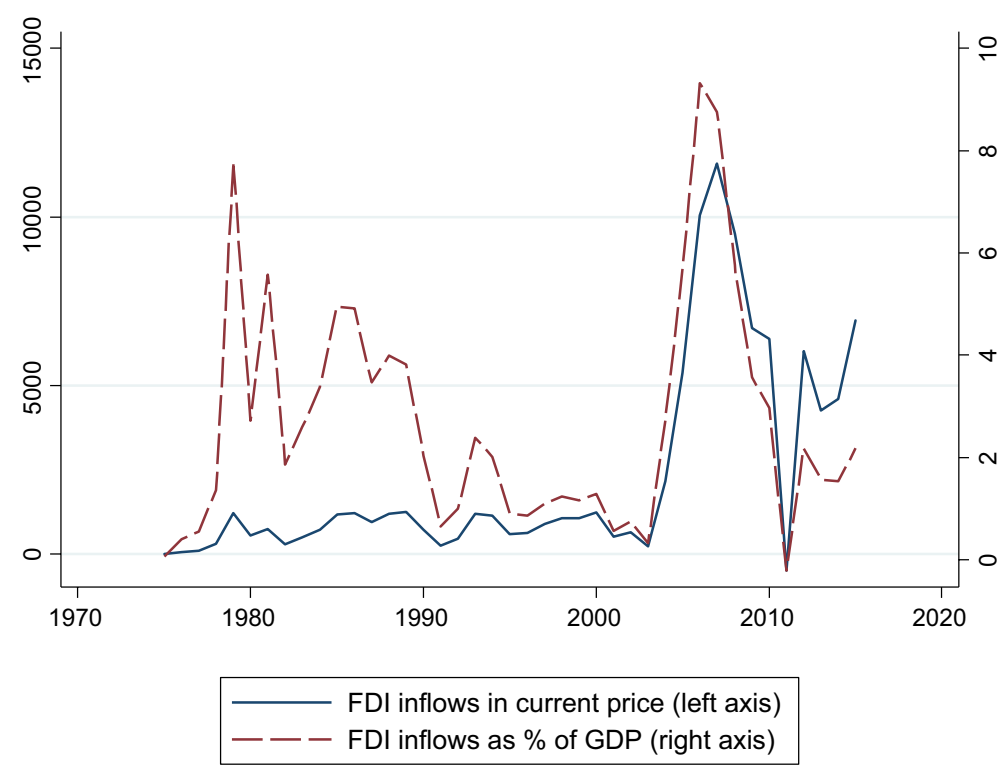

Fig. 1 FDI inflows in Egypt Source UNCTAD FDI/TNC database (www.unctad.org/fdistatistics)

inflows, the most important being tax exemptions for investment projects requiring advanced technology and modern methods of production.

The open-door policy has helped to shape Egypt's economy. In this section, we discuss the trends of Egypt's FDI inflows and income inequality (measured by the Gini coefficient) and their correlation, which provides background information for the subsequent empirical analysis.

\subsection{Trend of FDI inflows}

Figure 1 exhibits the trends of Egypt's FDI inflows in both current price and as a percentage of GDP over the period from 1975 to 2015. Before 2003, the FDI inflows in current prices are at a low and relatively stable level. In contrast, after 2003, the FDI inflows increase, but become more volatile. The low level of FDI inflows before 2003 suggests that despite the issuance of several investment laws that intend to attract FDI, the macroeconomic and political instability appears to prevent them from doing so. Such instability includes the high inflation (>20\%) and high unemployment (> 10\%) in the late 1980s, assassination of President Anwar Sadat in 1981, decreasing share of Arab countries in attracting FDI as a result of disrupted political relations following the Camp David in 1979, and recession in the beginning of implementing economic reform in Egypt. In addition, the low level of FDI inflows is also due to the events that Middle East witnessed in the beginning of 1990s (Iraq's invasion of Kuwait) and decreasing world FDI inflows from the slowdown in the world economy and the event of September 11, 2001. 
The FDI inflows grew approximately by 48 times from 2003 to 2007, reaching USD 11,578 million in 2007, owing primarily to improvement in the investment climate and improving macroeconomic environment in this period. For example, Law No. 88 (2003) guarantees the right to repatriate income earned in Egypt. Law No. 13 (2004) allows investors to start activities with temporary licenses, before obtaining the required licenses. Law No. 91 (2005) provides an investment incentive in the form of a discounted taxable net profits. Decree No. 548 (2005) grants foreigners the same legal rights as Egyptian nationals with regard to ownership of residential units in the tourist areas of Sidi Abdel-Raman, Hurghada, the Red Sea coast, including the beach resort of Hurghada, Ras Al-Hekma, and the Mediterranean coast in Matrouh Governorate.

In 2006, the Egyptian government launched a new strategy of public-private partnership to remove the barriers that prevent or discourage private investment in such basic services as water, electricity, gas, waste management, road building and transportation. In addition, the Egyptian government has also signed several inter-regional trade and investment agreements, for example with the European Union and Turkey. In 2004, the Ministry of Trade and Industry launched the National Suppliers Development Program, which provide assistance to Egyptian enterprises that supply multinational corporations operating in Egypt. These factors jointly promote FDI inflows into Egypt.

However, the increasing trend did not sustain, with the net FDI inflows dropping to the bottom of US\$ -483 million in 2011 , owing primarily to the political instability in 2011 (the Revolution of 25 January). The economic turbulence results in real GDP growth decreasing sharply from $5.1 \%$ in the fiscal year $2009-10$ to $1.8 \%$ in $2010-11$. The banks and stock market were temporarily closed, and manufacturers were unable to receive raw materials. Due to the deteriorating environment, many foreign investors halted the on-going investment, and some left Egypt.

The FDI inflows recovered after 2011, as democracy was restored and the subsequent stability improved investors' confidence. Consequently, Egypt received a positive FDI inflow of USD 6031 million in 2012, in contrast with the negative net inflow in 2011. In addition, Egypt has taken further steps to improve the business climate for foreign investors. For example, Law No. 12 (2012) allows foreign investors to invest in Sinai Peninsula under certain conditions. Decree No. 1115 (2012) established a Governmental Group for Settlement of Investment Disputes. Chaired by the Minister of Justice, the Group is authorized to investigate investors' complaints of public entities. In 2014, the Egyptian government invited foreign investors to participate in projects that took place in the Suez Canal Economic Zone, a major industrial and logistic services hub. The presidential Decree No. 17 (2015) permitted the government to provide lands in certain regions, free of charge, to investors meeting certain technical and financial requirements.

Regarding FDI as a percentage of GDP, it has a decreasing trend from 1975 to 2003, reaching $0.32 \%$ in 2003. The decreasing trend occurs as Egypt's economy grew while the FDI inflows remained relatively stable. After 2003, its trending follows that of the FDI inflows in current prices. From 2004 to 2006, the FDI as a percentage of GDP exhibits an upward trend, reaching $9.32 \%$ in 2006 . The upward 


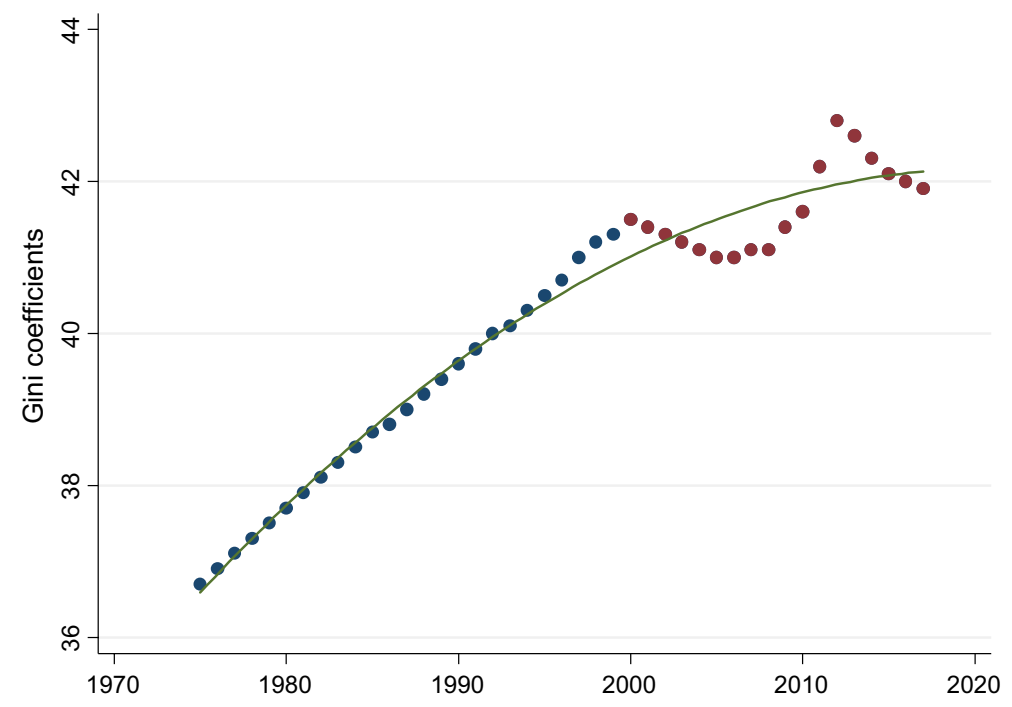

Fig. 2 Income inequality in Egypt Note Gini is post-tax and post-transfer. Source Standardized World Income Inequality Database v 9.1

trend then reverses, falling to $-0.21 \%$ in 2011 , which however recovers back to $2.18 \%$ in 2015 .

\subsection{Income inequality}

Since the open door policy in the mid-1970s, income inequality in Egypt, measured by the Gini coefficient sourced from the Standardized World Income Inequality Database (SWIID), has been on an increasing trend as exhibited in Fig. 2. The upward trending consists of two periods, one from 1975 to 2000 with a linear trend and the other from 2000 to 2017 with a nonlinear trend.

In the first period, the Gini coefficient increases from 36.7 in 1975 to 41.5 in 2000, following an almost linear upward trend. Thereafter, it becomes nonlinear, with periods of decreasing Gini coefficient (namely improving income inequality). In this period, the Gini coefficient peaks at 42.8 in 2012, suggesting a severe income inequality in Egypt, possibly because gains from high economic growth during the period 2004-2008 mostly benefited the wealthy and failed to significantly reduce poverty, especially in rural areas. In addition, Egypt have been negatively affected by the global financial crisis, followed by the political instability (the Revolution of 25 January) in 2011. Consequently, investment has decreased, and the unemployment rate has increased to $12.7 \%$ in 2012 .

Figure 3 shows the scatter plots of FDI inflows (both in current prices and as a $\%$ of GDP) versus income inequality in Egypt over the period 1975-2017, along with their Median spline fitting curves, which present the association between FDI inflows and income inequality. Regarding the FDI inflows in current prices 


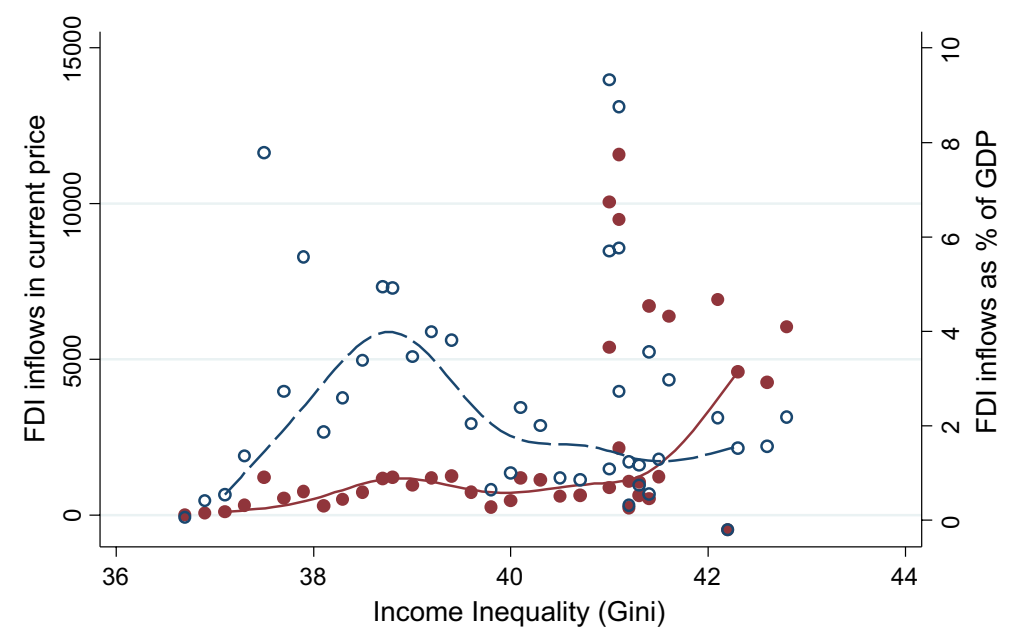

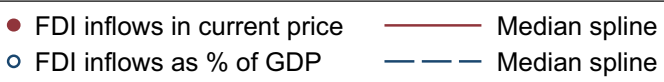

Fig. 3 FDI inflows versus income inequality Source UNCTAD FDI/TNC database (www.unctad.org/ fdistatistics) \& Standardized World Income Inequality Database v 9.1

(nominal), we can observe a clear positive correlation between them, namely a higher Gini coefficient is associated with higher FDI inflows (in current prices). In contrast, the association between income inequality and FDI inflows as a \% of GDP (real) is quite different, with its Median spline fitting curve having a negative slope in some ranges of the Gini coefficients. The scatter plots highlight a need to investigate the causality between FDI and income inequality in Egypt. Due to its position in the global value chains, ${ }^{2}$ there is a risk of outsourcing and exploitation of repressive labour conditions by multinational enterprises in Egypt, ${ }^{3}$ which can in turn affect income equality. Later, we will explore the causality in more details.

\section{Analytical framework}

\subsection{Channels of FDI impacts}

Researchers have established two theories to investigate the relationship between FDI and income inequality, namely the modernization theory and the dependency

\footnotetext{
${ }^{2}$ For example, Azmeh (2015) argues that the rules of origin facilitated the integration of Egypt and Jordan into the global value chains of Asian producers of textile and garments, after entering the qualifying industrial zone agreement with the US and the free trade agreement between Jordan and the US.

${ }^{3}$ We thank an anonymous reviewer for pointing this out.
} 
and world-systems theory, which give different views about the effect of FDI on income inequality (for more details see Roberts and Hite 2000).

The modernization theory, used to explain the process of societies' gradual transition from traditional to modern, dates to the early 1950s, and argues that developing economies tend to benefit from economic linkages with advanced economies. Through economic globalisation, for example FDI inflows, developing countries gain access to export markets, capital, and technology, which are essential for development (Mihalache-O'Keef and Li 2011).

Kuznets (1955) characterizes the link between economic development and income inequality as an inverted U-shaped curve. As one component of economic globalisation, the FDI inflows promote economic development, which in turn affects the host countries' income inequality through the Kuznets (1955) hypothesis (Kaulihowa and Adjasi 2018). Even though FDI initially stimulates growth in some leading sectors and regions in the host economies, and provides benefits to some skilled elites, eventually, growth in the leading sectors and regions facilitates more equal income distribution within a country (Pan-Long 1995).

In contrast, the dependency and world-systems theory views the link between FDI and income inequality from a core-periphery perspective, where the core is highly industrialized developed countries with abundant skilled labour and the periphery is developing countries with abundant unskilled labour. The theory emphasizes that the international capitalists can distort the economies of developing countries. Dependency theorists view the predatory behaviour of multinational enterprises creates a neo-colonies' economy through FDI. Thus, more FDI inflows in a country result in more foreign control of the host economy, and consequently a greater degree of income inequality in the country (Roberts and Hite 2000).

\subsection{Econometric model}

In light of the above theoretical discussions, we utilize the following econometric model to explore the impact of FDI inflows on income inequality in Egypt from 1975 to 2017 :

$$
\begin{gathered}
\mathrm{Gini}=\beta_{0}+\beta_{1} \mathrm{FDI}+\beta_{2} t+\beta_{3} \mathrm{TO}+\beta_{4} \mathrm{GDP}+\beta_{5} \mathrm{FD} \\
+\beta_{6} \mathrm{INF}+\beta_{7} \mathrm{NSE}+\beta_{8} \mathrm{URB}+\beta_{9} \mathrm{DYear}+\varepsilon
\end{gathered}
$$

where Gini represents the Gini coefficient; FDI stands for the FDI inflows; $t$ is the time trend; $T O$ denotes trade openness; GDP represents the gross domestic product per capita (constant 2010 US\$); FD denotes financial development; INF stands for the annual inflation rate, calculated from the GDP deflator; NSE represents the secondary school enrollment as a percentage of gross enrollment; $U R B$ is the urbanization rate; DYear is a dummy variable, taking a value of 1 if it is after 2000; and $\varepsilon$ is the error term.

FDI is the variable of interest, and a negative estimate of its coefficient suggests that FDI inflows reduces income inequality. The variable $t$ captures the time trend, as observed in Fig. 2. According to the Heckscher-Ohlin-Samuelson model 
(with two types of labour), developing countries tend to specialize in producing and exporting unskilled-labour-intensive goods because they are relatively well endowed with unskilled labour, which would result in an increase in the wages of unskilled labour relative to those of skilled labour, leading to a reduction in income inequality. Hence, we expect trade openness (TO) to negatively affect income inequality. The variable, GDP per capita $(G D P)$, controls for the potential influence of economic development on income inequality.

Conceptually, financial development $(F D)$ is expected to affect income inequality. An improvement in financial development can reduce income inequality, as betterdeveloped financial markets provide easier access of financial resources to the poor population, which in return enables them either to start small business ventures or increase human capital by investing in education for a better future (Shahbaz et al. 2015). However, the role of financial development is likely to depend on the level of economic development. Greenwood et al. (1990) suggest that financial development initially raises income inequality, and then reduces it as economic development reaches a certain stage. At a low level of economic development, access to financial intermediaries is restricted to a few people, mostly the wealthy households, because of high (fixed) transaction costs. Hence, an improvement of financial development benefits the wealthy and exacerbates income inequality. Nevertheless, as the economy develops over time, the poor households eventually gain financial access and benefit from financial development, which helps reduce income inequality.

Cardoso et al. (1995) suggest that inflation (INF) can raise income inequality in three ways. First, high wages have better indexation than low wages, and subsequently inflation affects low wage earners to a greater extent than high wage earners, resulting in an increase in income inequality. Second, the inflation tax increases the number of poor by wiping out the savings of the middle class, exacerbating income inequality. Third, inflation, particularly hyper-inflation, redistributes assets in the financial markets between creditors and debtors, in favour of the more capable group, which in turns affects income inequality.

Education (or human capital) is another factor that affects income inequality. Workers with higher education level (more human capital) tend to earn higher wages. In Eq. (1), we control this factor by the secondary school enrollment as a percentage of gross enrollment (NSE). Urbanization (URB) increases income inequality in the early stage of economic development, while in the latter stage it decreases income inequality (see, among others, Adams and Klobodu 2019; Kuznets 1955; Lewis 1954). In Eq. (1), we also include a dummy variable (DYear) to control for the structural change of the trend of Gini coefficient, as can be observed in Fig. 2.

In estimating Eq. (1), there exists a likely reverse causality from income inequality to FDI inflows, resulting in FDI being endogenous. First, multinational enterprises (MNEs) can purposely locate themselves in countries with high/low levels of income inequality (Jensen and Rosas 2007). MNEs can undertake vertical FDI and (re)locate their low-skilled activities to countries with higher inequality, to benefit from lower wages. Alternatively, MNEs may avoid countries with greater inequality due to concerns about social conflict, political instability, and limited effective demand as a result of a compromised middle class from high inequality (Herzer and Nunnenkamp 2013). Second, previous studies suggest that more equal income 
distribution is conducive to higher economic growth, which in turn attracts more FDI inflows (Herzer and Nunnenkamp 2013). The potential endogeneity of FDI will result in the coefficient estimates to be biased and inconsistent.

To address the endogeneity problem, we utilize the FDI inflows in Egypt's neighbouring countries, namely Morocco and Jordan, as excluded instruments in our estimations later. It is clear that when MNEs are considering whether to invest in Morocco and Jordan, they will not consider Egypt's income inequality issue. In addition, despite Egypt's income inequality can affect its FDI inflows through the effect on its economic growth, it is unlikely that the income inequality in Egypt will affect FDI inflows into Morocco and Jordan. Therefore, the FDI inflows in Morocco and Jordan are not correlated with the error term in Eq. (1), namely the excluded instruments are valid (validity). Since Egypt, Morocco and Jordan are neighbouring Arabic countries, their FDI inflows are not surprisingly correlated with each other, namely the excluded instruments are relevant (relevance). Later in our estimations, we also use statistical tests to check the validity and relevance of the two excluded instruments.

\section{Data}

The data of FDI inflows are sourced from the United Nations Conference on Trade and Development (UNCTAD). The Gini coefficient (post tax and transfer), measurement of income inequality, is obtained from SWIID (version 9.1). The other data come from the World Bank Development Indicators. Our sample covers the period from 1975 to 2017, chosen based on data availability.

Gini coefficient is the most used measurement of income inequality. SWIID provides comparable Gini coefficients for 196 countries since 1960. For the Gini coefficient in Egypt, the other sources, such as the World Bank database and the Central Agency for Public Mobilization and Statistics of Egypt (CAMPAS), do not have sufficient data, for example many years' data are missing, making it unsuitable for our estimations. In addition, SWIID data are fully comparable across countries and time (for more details, see Solt 2020).

The FDI inflows $(F D I)$ are measured as a percentage of gross fixed capital formation (the ratio of FDI inflows in current price against the gross fixed capital formation). Trade openness $(T O)$ is measured as total imports and exports over GDP. The GDP per capita $(G D P)$ is in constant 2010 US\$. We use domestic credit to the private sector as a percentage of GDP to measure financial development $(F D)$, which is a standard measurement of financial development and has been used widely in the empirical literature to examine the relationship between financial development and income inequality (see for example Clarke et al. 2006; Jauch and Watzka 2016; Seven and Coskun 2016; Shahbaz et al. 2015).

The secondary school enrollment as a percentage of gross enrollment (NSE) controls for the influence of education (human capital). However, its time series has missing values in the years 1998, 2005, 2006, 2007, and 2008, which we interpolate for the estimation purpose. The annual inflation rate (INF) is calculated, 
Table 1 Variable definition and summary statistics

\begin{tabular}{llrrrr}
\hline Variable & Definition & Mean & Std. Dev & Min & Max \\
\hline GINI & Gini Coefficient & 40.12 & 1.72 & 36.7 & 42.8 \\
FDI & FDI inflows as a \% of gross fixed capital formation & 13.11 & 10.92 & -1.25 & 49.81 \\
GDP & GDP per capita (constant 2010US\$) & 1819.22 & 591.44 & 802.75 & 2817.32 \\
$T O$ & (Imports + Exports)/GDP & 50.76 & 11.17 & 30.25 & 74.46 \\
$F D$ & Domestic credit to the private sector as a \% of GDP & 32.61 & 12.04 & 13.94 & 54.93 \\
$I N F$ & Annual inflation rate based on the GDP deflator & 10.93 & 5.86 & -2.20 & 24.73 \\
$N S E$ & The secondary school enrolment as a \% of gross & 68.31 & 13.40 & 38.83 & 86.71 \\
& $\quad$ enrolment & & & & 43.95 \\
$N R B$ & The percentage of population living in the urban area & 43.24 & 0.45 & 42.66 & 43.95 \\
$N=43$ & & & & & \\
\hline
\end{tabular}

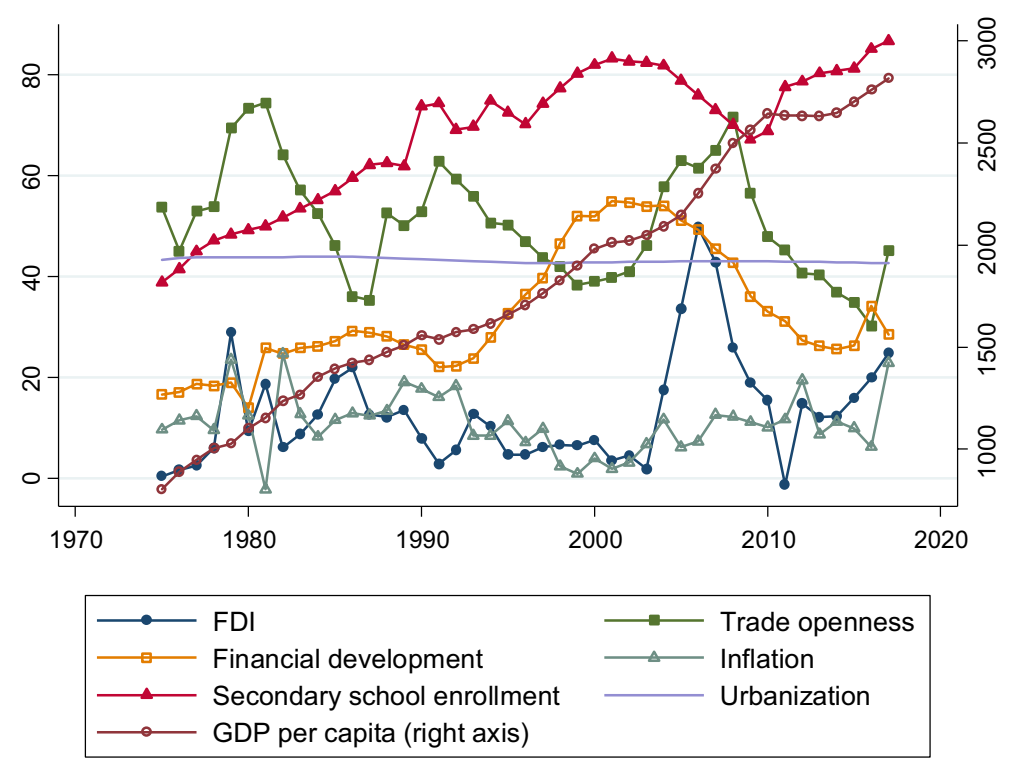

Fig. 4 Time series of explanatory variables Source World Development Indicators \& UNCTAD FDI/ TNC database

based on the GDP deflator. The urbanization rate (URB) is measured by the percentage of the population living in the urban area. Table 1 shows the definitions and summary statistics of these variables, and Fig. 4 presents their time series.

Table 2 reports the results of the augmented Dickey Fuller test and PhillipsPerron test. Except for the inflation rate $(I N F)$, the time series of all the other variables are $\mathrm{I}(1)$. The time series of inflation rate is stationary at the level, namely $\mathrm{I}(0)$. Later in our regressions, we will check whether the regression residuals are stationary or not. Stationary residuals suggest that income inequality and the right-hand side variables are cointegrated. 


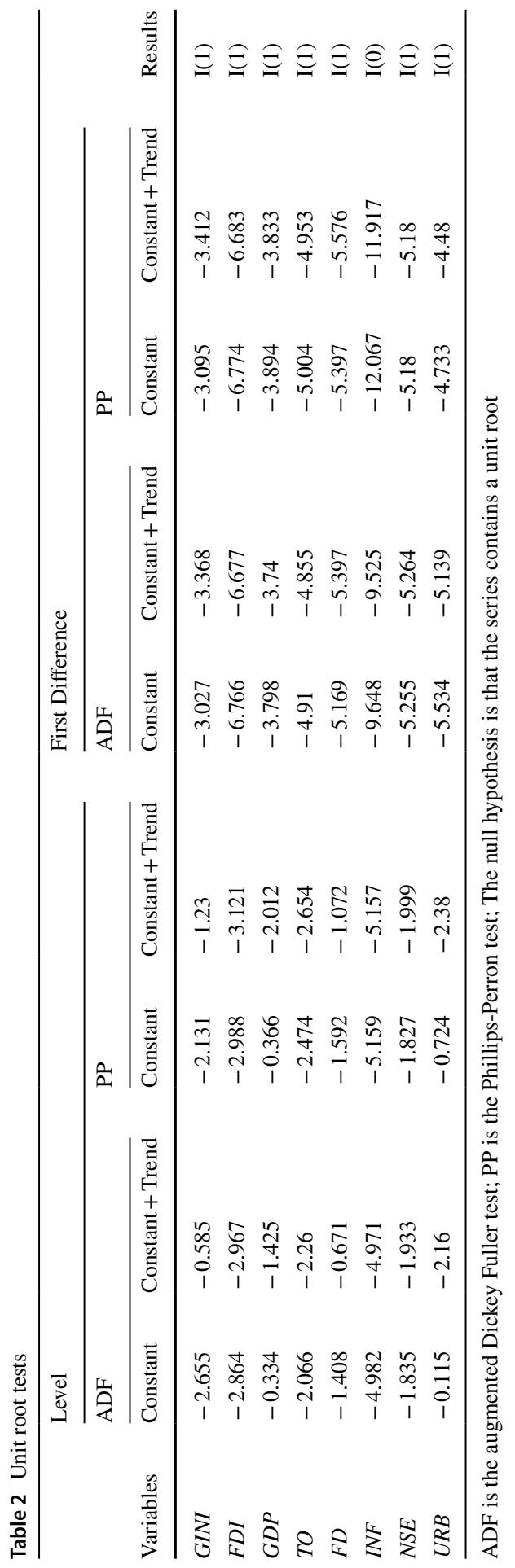


Table 3 Regression results

\begin{tabular}{|c|c|c|c|c|}
\hline Variables & (1) & (2) & (3) & (4) \\
\hline$t$ & $\begin{array}{l}0.138 * * * \\
(0.00933)\end{array}$ & $\begin{array}{l}0.154 * * * \\
(0.00867)\end{array}$ & $\begin{array}{l}0.151 * * * \\
(0.00863)\end{array}$ & $\begin{array}{l}0.151 * * * \\
(0.00810)\end{array}$ \\
\hline$F D I$ & $\begin{array}{l}-0.0216^{* *} \\
(0.00854)\end{array}$ & $\begin{array}{l}-0.0188^{* * * *} \\
(0.00672)\end{array}$ & $\begin{array}{l}-0.0195 * * * \\
(0.00575)\end{array}$ & $\begin{array}{l}-0.0196^{* * *} \\
(0.00588)\end{array}$ \\
\hline DYear & & $\begin{array}{l}-0.885^{* * *} \\
(0.211)\end{array}$ & $\begin{array}{l}-0.618^{* *} \\
(0.250)\end{array}$ & $\begin{array}{l}-0.545^{* * *} \\
(0.247)\end{array}$ \\
\hline$T O$ & & $\begin{array}{l}-0.00142 \\
(0.00648)\end{array}$ & $\begin{array}{l}0.000216 \\
(0.00596)\end{array}$ & $\begin{array}{l}0.000403 \\
(0.00611)\end{array}$ \\
\hline$F D$ & & $\begin{array}{l}0.0264 * * * \\
(0.00541)\end{array}$ & $\begin{array}{l}0.0140 * \\
(0.00815)\end{array}$ & $\begin{array}{l}0.0106 \\
(0.00809)\end{array}$ \\
\hline$I N F$ & & $\begin{array}{l}0.00398 \\
(0.00845)\end{array}$ & $\begin{array}{l}-0.00182 \\
(0.00798)\end{array}$ & $\begin{array}{l}-0.00316 \\
(0.00799)\end{array}$ \\
\hline$U R B$ & & & $\begin{array}{l}0.0708 \\
(0.231)\end{array}$ & $\begin{array}{l}-0.318 \\
(0.368)\end{array}$ \\
\hline$N S E$ & & & $\begin{array}{l}0.0282 * * \\
(0.0120)\end{array}$ & $\begin{array}{l}0.0422 * * * \\
(0.0153)\end{array}$ \\
\hline$G D P$ & & & & $\begin{array}{l}0.00199 \\
(0.00165)\end{array}$ \\
\hline Constant & $\begin{array}{l}37.37 * * * \\
(0.234)\end{array}$ & $\begin{array}{l}36.52 * * * \\
(0.437)\end{array}$ & $\begin{array}{l}36.86 * * * \\
(0.436)\end{array}$ & $\begin{array}{l}36.96 * * * \\
(0.435)\end{array}$ \\
\hline Observations & 43 & 43 & 43 & 43 \\
\hline R-squared & 0.941 & 0.971 & 0.976 & 0.978 \\
\hline
\end{tabular}

Standard errors in parentheses; Standard errors are autocorrelation robust; URB, NSE, and GDP are projections of their original variables onto the subspace spanned by time $(t)$ and a vector of 1 to account for their high correlation with time; $* * * p<0.01, * * p<0.05, * p<0.1$

\section{Estimation results}

In estimating Eq. (1), it is likely that the right-hand side variables have multicollinearity issue. For example, the correlation between time trend $(t)$ and GDP per capita $(G D P)$, secondary school enrolment (NSE), urbanisation rate (URB), and they year 2000 dummy (DYear) are as high as 0.9921, 0.8741, -0.7994, and 0.8547 , respectively. After regressing the Gini coefficient against all the righthand size variables, the variance inflation factors (VIF) for time trend $(t)$, GDP per capita $(G D P)$, secondary school enrolment (NSE), are urbanisation rate $(U R B)$ are as high as $546.79,325.92,17.93$, and 12.39, suggesting existence of multicollinearity issue. Hence, we first project $N S E, U R B$, and GDP onto the subspace spanned by time trend $(t)$ and a vector of one, and use the projection in the regressions.

Table 3 reports the regression results where we assume FDI is exogenous. We start from a minimal specification with only the time trend $(t)$ and FDI inflows $(F D I)$, and gradually build up to the specification with full set of right-hand side 
Table 4 Regression results

\begin{tabular}{|c|c|c|c|c|}
\hline Variables & (1) & (2) & (3) & (4) \\
\hline$t$ & $\begin{array}{l}0.139 * * * \\
(0.00579)\end{array}$ & $\begin{array}{l}0.153 * * * \\
(0.00779)\end{array}$ & $\begin{array}{l}0.150^{* * *} \\
(0.00738)\end{array}$ & $\begin{array}{l}0.149 * * * \\
(0.00712)\end{array}$ \\
\hline$F D I$ & $\begin{array}{l}-0.0264^{* * * *} \\
(0.00973)\end{array}$ & $\begin{array}{l}-0.0169^{* *} \\
(0.00832)\end{array}$ & $\begin{array}{l}-0.0142 * \\
(0.00732)\end{array}$ & $\begin{array}{l}-0.0154 * * \\
(0.00704)\end{array}$ \\
\hline DYear & & $\begin{array}{l}-0.892^{* * * *} \\
(0.184)\end{array}$ & $\begin{array}{l}-0.642 * * * \\
(0.207)\end{array}$ & $\begin{array}{l}-0.565^{\text {**** }} \\
(0.204)\end{array}$ \\
\hline TO & & $\begin{array}{l}-0.00226 \\
(0.00586)\end{array}$ & $\begin{array}{l}-0.00220 \\
(0.00540)\end{array}$ & $\begin{array}{l}-0.00150 \\
(0.00520)\end{array}$ \\
\hline$F D$ & & $\begin{array}{l}0.0261 * * * \\
(0.00538)\end{array}$ & $\begin{array}{l}0.0136 * * \\
(0.00678)\end{array}$ & $\begin{array}{l}0.0103 \\
(0.00686)\end{array}$ \\
\hline INF & & $\begin{array}{l}0.00355 \\
(0.00951)\end{array}$ & $\begin{array}{l}-0.00291 \\
(0.00911)\end{array}$ & $\begin{array}{l}-0.00400 \\
(0.00882)\end{array}$ \\
\hline$U R B$ & & & $\begin{array}{l}0.0694 \\
(0.203)\end{array}$ & $\begin{array}{l}-0.317 \\
(0.306)\end{array}$ \\
\hline$N S E$ & & & $\begin{array}{l}0.0276 \text { *** } \\
(0.00956)\end{array}$ & $\begin{array}{l}0.0416^{* * *} \\
(0.0125)\end{array}$ \\
\hline$G D P$ & & & & $\begin{array}{l}0.00198 \\
(0.00121)\end{array}$ \\
\hline Constant & $\begin{array}{l}37.40^{* * * *} \\
(0.147)\end{array}$ & $\begin{array}{l}36.57 * * * \\
(0.385)\end{array}$ & $\begin{array}{l}36.98 * * * \\
(0.377)\end{array}$ & $\begin{array}{l}37.05 * * * \\
(0.369)\end{array}$ \\
\hline Observations & 43 & 43 & 43 & 43 \\
\hline Under-identification test & $11.022 * * *$ & $8.59 * *$ & $13.422^{* * *}$ & $12.6^{* * *}$ \\
\hline Weak identification test & 11.214 & 7.655 & 8.635 & 10.064 \\
\hline Over-identification test & 1.606 & 0.954 & 0.029 & 0.619 \\
\hline Endogeneity test & 2.125 & $<0.1$ & 0.018 & 0.667 \\
\hline R-squared & 0.9399 & 0.9714 & 0.989 & 0.9756 \\
\hline
\end{tabular}

Standard errors in parentheses; Standard errors are autocorrelation robust; URB, NSE, and GDP are projections of their original variables onto the subspace spanned by time $(t)$ and a vector of 1 to account for their high correlation with time; *** $p<0.01, * * p<0.05, * p<0.1$

variables. We also account for the potential autocorrelation in the error term by computing the autocorrelation-robust standard errors in Table 3.

In each specification, we predict the residuals after regression and test its stationarity by using the augmented Dickey Fuller test. In all regressions, the residuals are $\mathrm{I}(0)$, suggesting a cointegration between income inequality and the right-hand side variables. Note our regressions capture the long run relationship between income inequality and FDI inflows (and other explanatory variables). We do not explore the short run dynamics in this study due to the relatively short time frame of our sample.

As discussed in Sect. 4, FDI inflows $(F D I)$ are likely to be endogenous, and we use the FDI inflows in Morocco and Jordan as excluded instruments. Table 4 reports the regression results with these excluded instruments, where we utilize the limited information maximum likelihood (LIML) estimator in the estimations which is more 
robust to the potential weak instrument issue. Same as Table 3, we follow a building-up-specification approach. In each regression, we test the stationarity of predicted residuals, which all reject the null hypothesis of unit root. The standard errors reported in Table 4 are autocorrelation robust.

In each regression in Table 4, we conduct the under-identification test (Kleibergen-Paap rk LM statistic) to check the relevance of instruments, weak identification test (Kleibergen-Paap rk Wald F statistic) to check whether the instruments are weak, overidentification test (Sargan statistic) to check the validity of instruments, and endogeneity test to check whether FDI is endogenous or not. For example, for column 2 in Table 4, the Kleibergen-Paap rk LM statistic for the under-identification test is 8.59 with a $p$-value $<0.05$, rejecting the null hypothesis of irrelevance at 5 per cent level. The Kleibergen-Paap rk Wald F statistic for the weak identification test is 7.655, below the Stock-Yogo weak identification test critical value of $10 \%$ maximal LIML size (8.68) but above its critical value of $15 \%$ maximal LIML size (5.33). For the over-identification test, the Sargan statistic is 0.954 with a p-value of 0.3286 , failing to reject the null hypothesis of valid instruments at the 5 per cent level. The endogeneity test fails to reject the null hypothesis of no endogeneity of FDI at the 5 per cent level, with a test statistic $<0.01$ and the associated $p$-value of 0.9831 . The test results are similar in the other specifications, and therefore we use Table 3 in our interpretation.

In column 2 of Table 3, the coefficient estimate of time trend $(t)$ is 0.154 , statistically significant at the one per cent level, confirming the time trend that can be observed in Fig. 2. The coefficient of FDI, the variable of interest, is estimated to be -0.0188 , statistically significant at the one per cent level. Therefore, a one per cent increase of FDI inflows (as a percentage of gross fixed capital formation) results in a decrease of income inequality (Gini coefficient) by 0.0188 . The statistically significant negative impact of FDI inflows supports the modernization theory. As suggested by Mihalache-O'Keef and Li (2011), FDI inflows can help developing countries gain access to export markets, capital, and technology, which in turn promotes economic development and subsequently alleviates the income inequality issue.

In addition, it is likely that institutions play a role in the FDI-income inequality nexus. ${ }^{4}$ As discussed previously, a number of investment laws have been established, which facilitates foreign businesses to operate in Egyptian market and in turn can promote transmission of the benefits of FDI inflows, leading to reduction of inequality. Egyptian government aims to reduce the poverty rate to 6 per cent by 2022, for which a number of measures have been implemented, for example the direct assistance to the poor through Ministry of Social Affairs, free social services such as health and education, and support to work and income generating activities through its Social Fund for Development. On the one hand, these measures promote income equality directly, while on the other hand they indirectly influence the FDI-income inequality nexus by promoting human capital which facilitates transmission of FDI benefits.

\footnotetext{
${ }^{4}$ Due to lack of data, we are not able to include institutions in the estimations.
} 
The coefficient trade openness $(T O)$ is estimated to be negative, but not statistically significant at the five per cent level. Conceptually, one expects that trade openness allows Egypt to take a full advantage of its factor endowment and comparative advantages, which promotes economic development and in turn reduces income inequality in Egypt. The estimate of coefficient of DYear is negative and statistically significant at the one per cent level, which is consistent with Fig. 2. It is clear in Fig. 2 that after 2000, the Gini coefficient in Egypt displays a decreasing trend in some years. Inflation rate $(I N F)$ and urbanisation $(U R B)$ appear not to exert statistically significant influence on income inequality.

The coefficient of financial development $(F D)$ is statistically significant at the five per cent level in column 2 of Table 3, which becomes not significant in the full specification (column 4). Hence, the role of FD is sensitive to different specifications. The coefficient of GDP is not significant at the five per cent level, which occurs as its effect is captured by time trend.

In the regressions of Tables 3 and 4, the dependent variable is the post-tax and post-transfer Gini coefficient (SWIID 9.1), which is affected by the social spending and other income redistribution measures. ${ }^{5}$ As a robustness check, we also use the pre-tax and pre-transfer Gini coefficient in the estimations. We do not report these regression results, in order to save space, which however are available upon request. The point estimates of the coefficient of FDI continue to be negative and statistically significant at the five per cent level, and the magnitude is within one standard error of those in Table 3. Hence, the negative effect of FDI inflows is robust to alternative measure of Gini coefficient.

The negative impacts of FDI inflows on income inequality in Egypt presents significant implications for policymakers in Egypt and more broadly the Middle East and North Africa (MENA) countries. While FDI can benefit economic development, one frequently worries about its potential side effects, such as to exacerbate income inequality in the host country. Globalisation (e.g. trade and FDI inflows that provide preferential access to the USA, European and Chinese markets) does not automatically promise a better living standard for working class in Egypt. ${ }^{6}$ Nevertheless, our empirical estimations suggest that FDI inflows in Egypt lead to an improvement of income inequality. In light of this relationship, policies that encourage FDI inflows (e.g. the investment laws) have an unintended consequence of reducing inequality. Hence, despite Egyptian government does not have a professed policy goal of reducing inequality, it is beneficial to continue and strengthen the open-door policy, which has an added benefit of improving income inequality and can in turn contribute to poverty alleviation in Egypt, one important part of "Egypt's Vision 2030".

\footnotetext{
5 We thank one anonymous reviewer for pointing this out.

6 We thank one anonymous reviewer for pointing this out.
} 


\section{Concluding remarks}

Since the mid-1970s, Egypt has introduced various laws, increasing its openness to foreign investors, thereby attracting substantial FDI inflows. At the same time, Egypt's economy suffers from an increasing income inequality problem. Nevertheless, little attention has been devoted to exploring the impact of FDI inflows on income inequality in Egypt, despite some previous studies of the distributional effect of FDI include Egypt as part of their panel data.

In light of this gap, this study extends existing literature by focusing on the effect of FDI on income inequality in Egypt, using time series data from 1975 to 2017. Our estimations find that FDI inflows significantly and negatively affect Egypt's income inequality, measured by the Gini coefficient, with a one per cent increase of FDI inflows (as a percentage of gross fixed capital formation) leading to 0.0188 reduction of Gini coefficient. The statistically significant negative impact of FDI inflows is consistent with the prediction of the modernization theory. Our regressions are robust to different specifications and potential endogeneity of FDI inflows.

Given our finding, Egypt's policymakers should not be concerned about attracting more foreign investment to take advantages of the benefit of FDI inflows (for example transfer of management skills and modern technology, exporting market access and human capital development), as attracting more foreign investment does not conflict with reducing the gap between rich and poor.

Funding Open Access funding enabled and organized by CAUL and its Member Institutions. Hebatalla Rezk acknowledges the funding support by the Ministry of Higher Education of the Arab Republic of Egypt.

Open Access This article is licensed under a Creative Commons Attribution 4.0 International License, which permits use, sharing, adaptation, distribution and reproduction in any medium or format, as long as you give appropriate credit to the original author(s) and the source, provide a link to the Creative Commons licence, and indicate if changes were made. The images or other third party material in this article are included in the article's Creative Commons licence, unless indicated otherwise in a credit line to the material. If material is not included in the article's Creative Commons licence and your intended use is not permitted by statutory regulation or exceeds the permitted use, you will need to obtain permission directly from the copyright holder. To view a copy of this licence, visit http://creativecommons.org/licen ses/by/4.0/.

\section{References}

Adams S (2008) Globalization and income inequality: implications for intellectual property rights. J Policy Model 30(5):725-735

Adams S, Klobodu EKM (2019) Urbanization economic structure political regime and income inequality. Soc Indic Res 142(3):971-95

Alderson AS, Nielsen F (1999) Income inequality, development, and dependence: a reconsideration. Am Sociol Rev 64(4):606-631

Alderson A, Nielsen F (2002) Globalization and the great U-Turn: income inequality trends in 16 OECD Countries. Am J Sociol 107(5):1244-1299 
Azmeh S (2015) Transient global value chains and preferential trade agreements: rules of origin in US trade agreements with Jordan and Egypt. Camb J Reg Econ Soc 8(3):475-490

Bhaumik SK, Gelb S (2005) Determinants of entry mode choice of MNCs in emerging markets : evidence from South Africa and Egypt. Emerg Mark Financ Trade 41(2):5-24

Bussmann M, Oneal J, de Soysa I (2005) The effect of globalization on national income inequality. Comp Soc 4(3-4):285-312

Cardoso E, de Barros RP, Urani A (1995) Inflation and unemployment as determinants of inequality in Brazil: the 1980s. In: Rudiger D, Sebastian E (eds) Reform, recovery, and growth: Latin America and the Middle East. University of Chicago Press, Chicago, pp 151-176

Chintrakarn P, Herzer D, Nunnenkamp P (2012) FDI and income inequality: evidence from a panel of US states. Econ Inq 50(3):788-801

Choi C (2006) Does foreign direct investment affect domestic income inequality? Appl Econ Lett 13(12):811-814

Clarke GRG, Xu LC, Zou H-f (2006) Finance and income inequality: what do the data tell us? South Econ J 72(3):578-596

CNUCED (2018), World investment report 2018: Investment and new industrial policies (UN)

Greenwood J, Jovanovic B (1990) Financial development, growth, and the distribution of income. J Polit Econ 98:1076-1107

Grimalda G, Barlow D, Meschi E (2010) Varieties of capitalisms and varieties of performances: accounting for inequality in post-Soviet Union transition economies. Int Rev Appl Econ 24(3):379-403

Hanafy S, Marktanner M (2019) Sectoral FDI absorptive capacity and economic growth-empirical evidence from Egyptian governorates. J Int Trade Econ Dev 28(1):57-81

Herzer D, Nunnenkamp P (2013) Inward and outward FDI and income inequality: evidence from Europe. Rev World Econ 149(2):395-422

Herzer D, Hühne P, Nunnenkamp P (2014) FDI and income inequality—evidence from Latin American economies. Rev Dev Econ 18(4):778-793

Jauch S, Watzka S (2016) Financial development and income inequality: a panel data approach. Empir Econ 51(1):291-314

Jensen NM, Rosas G (2007) Foreign direct investment and income inequality in Mexico 1990-2000. Int Org. https://doi.org/10.1017/S0020818307070178

Kaulihowa T, Adjasi C (2018) FDI and income inequality in Africa. Oxf Dev Stud 46(2):250-265

Kuznets S (1955) Economic growth and income inequality. Am Econ Rev 45(1):1-28

Lee J-E (2010) Inequality in the globalizing Asia. Appl Econ 42(23):2975-2984

Lee C-S, Nielsen F, Alderson AS (2007) Income inequality, global economy and the state. Soc Forces 86(1):77-111

Lewis WA (1954) Economic development with unlimited supplies of labour. Manch Sch 22(2):139-191

Lin S-C, Kim D-H, Wu Y-C (2013) Foreign direct investment and income inequality: human capital matters. J Reg Sci 53(5):874-896

Lin S-C, Kim D-H, Lee Y-H (2015) Financial development and the FDI-inequality nexus. Contemp Econ Policy 33(3):513-534

Mah JS (2002) The impact of globalization on income distribution: the Korean experience. Appl Econ Lett 9(15):1007-1009

Mah JS (2013) Globalization, decentralization and income inequality: the case of China. Econ Model 31:653-658

Mahler VA, Jesuit DK, Roscoe DD (1999) Exploring the impact of trade and investment on income inequality: a cross-national sectoral analysis of the developed countries. Comp Pol Stud 32(3):363-395

Massoud N (2008) Assessing the employment effect of FDI inflows to Egypt: does the mode of entry matter', International Conference on The Unemployment Crisis in the Arab Countries, 17-18

Mihalache-O'Keef A, Li Q (2011) Modernization vs. dependency revisited: effects of foreign direct investment on food security in less developed countries. Int Stud Quart 55(1):71-93

Milanovic B (2005) Can we discern the effect of globalization on income distribution? Evidence from household surveys. World Bank Econ Rev 19(1):21-44

Naguib RI, Fathi, (2011) Foreign direct investment, privatisation and economic growth in the developing countries: the cases of Egypt and Argentina. University of the West of England, Bristol

Nunnenkamp P, Schweickert R, Wiebelt M (2007) Distributional effects of FDI: how the interaction of FDI and economic policy affects poor households in Bolivia. Dev Pol Rev 25(4):429-450

Pan-Long T (1995) Foreign direct investment and income inequality: further evidence. World Dev 23(3):469-483 
Ravinthirakumaran K, Ravinthirakumaran N (2018) The impact of foreign direct investment on income inequality: a panel autogressive distributed lag approach for the Asia-Pacific economic cooperation developing economies. Asia-Pac Sustain Dev J 2018(1):57-84

Reuveny R, Li Q (2003) Economic openness, democracy, and income inequality: an empirical analysis. Comp Pol Stud 36(5):575-601

Ridzuan AR, Noor AHM, Ahmed EM (2014) To what extent are the social inequality impacts Of FDI in the selected asean? Appl Econ Int Dev 14(1):189-202

Roberts JT, Hite AB (2000) From modernization to globalization: perspectives on development and social change. Wiley, Hoboken

Seven U, Coskun Y (2016) 'Does financial development reduce income inequality and poverty? Evidence from Emerging Countries. Emerg Markets Rev 26:34-63

Shahbaz M et al (2015) Financial development and income inequality: is there any financial Kuznets curve in Iran? Soc Indic Res 124(2):357-382

Solt F (2020) Measuring income inequality across countries and over time: the standardized world income inequality database. Soc Sci Q 101(3):1183-1199

Sylwester K (2005) Foreign direct investment, growth and income inequality in less developed countries. Int Rev Appl Econ 19(3):289-300

Ucal M, Haug AA, Bilgin MH (2016) Income inequality and FDI: evidence with Turkish data. Appl Econ 48(11):1030-1045

Verme P et al (2014) Inside inequality in the Arab Republic of Egypt: facts and perceptions across people time and space. The World Bank, USA

Wan G, Lu M, Chen Z (2007) Globalization and regional income inequality: empirical evidence from within China. Rev Income Wealth 53(1):35-59

Wei K, Yao S, Liu A (2009) Foreign direct investment and regional inequality in China. Rev Dev Econ 13(4):778-791

Yu K et al (2011) Foreign direct investment and China's regional income inequality. Econ Model 28(3):1348-1353

Zhang X, Zhang KH (2003) How does globalisation affect regional inequality within a developing country? Evidence from China. J Dev Stud 39(4):47-67

Publisher's Note Springer Nature remains neutral with regard to jurisdictional claims in published maps and institutional affiliations. 